\title{
Imunização e desigualdade de gênero: a construção da imagem da mulher nos primeiros atos de vacinação contra a covid-19
}

\author{
Immunization and gender inequality: the construction of the image of \\ women in the first vaccination acts against covid-19
}

\section{Inmunización y desigualdad de género: la construcción de la imagen de la mujer en los primeros actos de vacunación contra covid-19}

Carla Montuori Fernandes ${ }^{1, a}$

carla.montuori@docente.unip | https://orcid.org/0000-0002-7625-8070

Pedro Farnese $e^{1,2, b}$

pedro.farnese@ifsudestemg.edu.br | https://orcid.org/0000-0003-0010-7281

Janete Monteiro Garcia ${ }^{1, c}$

jane_s monteiro@yahoo.com.br | https://orcid.org/000o-0002-4848-5882

Paolo Demuru ${ }^{1, d}$

paolodemuru@gmail.com | https://orcid.org/0000-0003-1559-9530

${ }^{1}$ Universidade Paulista, Programa de Pós-Graduação em Comunicação. São Paulo, SP, Brasil.

${ }^{2}$ Instituto Federal do Sudeste de Minas Gerais, Assessoria de Comunicação do Campus Juiz de Fora. Juiz de Fora, MG, Brasil.

a Doutorado em Ciências Sociais pela Pontifícia Universidade Católica de São Paulo.

b Mestrado em Comunicação pela Universidade Federal de Juiz de Fora.

c Mestrado em Comunicação pela Universidade Paulista.

d Doutorado em Semiótica pela Università di Bologna.

\section{RESUMO}

O estudo tem por objetivo analisar as valências simbólicas identificadas em notícias publicadas no Portal G1 de todos os estados brasileiros sobre os primeiros atos de vacinação contra a covid-19, relacionando-os, em particular, às questões de raça e gênero com foco nas mulheres e sua posição na sociedade. Nessa perspectiva busca-se responder, sob a ancoragem da semiótica de Algirdas Julien Greimas, como a mulher foi representada em cada estado. Os resultados retratam as mulheres como sujeito social 'frágil' e 'dependente' do Estado como 'Pai-Provedor' ao lado do uso de mulheres negras representativas de 'minorias' que remetem a uma ideia de um Brasil diverso e miscigenado. As conclusões evidenciam que a visibilidade conferida à mulher nas campanhas de vacinação disputou espaço com representações de caráter sexista $\mathrm{e}$ racista.

Palavras-chave: Visibilidade midiática; Representações; Gênero; Jornalismo; Semiótica. 


\section{ABSTRACT}

The study aims to analyze the symbolic valences identified in news published on the G1 Portal from all Brazilian states about the first acts of vaccination against covid-19, relating them to issues of race and gender with a focus on women and their position in society. From this perspective, we seek to answer, under the anchorage of Algirdas Julien Greimas' semiotics, how women were represented in each state. The results portray women as a 'fragile' and 'dependent' social subject, from the State as a 'Father-Provider', alongside the use of black women representing 'minorities' that refer to an idea of a diverse and miscegenated Brazil. The conclusions show that the visibility given to women in vaccination campaigns disputed space with sexist and racist representations.

Keywords: Media visibility; Representations; Genre; Journalism; Semiotics.

\section{RESUMEN}

El estudio tiene como objetivo analizar las valencias simbólicas identificadas en las noticias publicadas en el Portal G1 de todos los estados brasileños sobre los primeros actos de vacunación contra el covid-19, relacionándolos, en particular, con cuestiones de raza y género, con un enfoque en las mujeres y su posición en la sociedad. Desde esta perspectiva, buscamos responder, bajo el anclaje de la semiótica de Algirdas Julien Greimas, cómo estaban representadas las mujeres en cada estado. Los resultados retratan a la mujer como sujeto social 'frágil' y 'dependiente' del Estado como 'Padre-Proveedor' junto con el uso de mujeres negras representativas de 'minorias' que remiten a una idea de un Brasil diverso y mestizo. Las conclusiones muestran que la visibilidad dada a las mujeres en las campañas de vacunación disputaba espacio con representaciones sexistas y racistas.

Palabras clave: Visibilidad de los medios; Representaciones; Género; Periodismo; Semiótica.

Contribuição dos autores:

Concepção e desenho do estudo: Pedro Farnese e Janete Monteiro Garcia.

Aquisição, análise ou interpretação dos dados: Pedro Farnese e Janete Monteiro Garcia.

Redação do manuscrito: Pedro Farnese e Janete Monteiro Garcia.

Revisão crítica do conteúdo intelectual: Carla Montuori Fernandes e Paolo Demuru.

Declaração de conflito de interesses: não há.

Fontes de financiamento: Coordenação de Aperfeiçoamento de Pessoal de Nível Superior (Capes).

Considerações éticas: não há.

Agradecimentos/Contribuições adicionais: não há.

Histórico do artigo: submetido: 9 jun. 2021 | aceito: 15 set. 2021 | publicado: 10 nov. 2021.

Apresentação anterior: não há.

Licença CC BY-NC atribuição não comercial. Com essa licença é permitido acessar, baixar (download), copiar, imprimir, compartilhar, reutilizar e distribuir os artigos, desde que para uso não comercial e com a citação da fonte, conferindo os devidos créditos de autoria e menção à Reciis. Nesses casos, nenhuma permissão é necessária por parte dos autores ou dos editores. 


\section{INTRODUÇÃO}

Este artigo busca analisar as valências simbólicas (GREIMAS; COURTÉS, 2008) que são acionadas nos primeiros atos de vacinação contra a covid-19 em todos os estados do Brasil, em particular aquelas relacionadas à mulher e à sua posição na sociedade.

Em um contexto de vulnerabilidade humana acarretada pela pandemia do novo Coronavírus, decretada pela Organização Mundial de Saúde (OMS) em março de 2020, a descoberta de imunizantes em tempo recorde foi uma conquista da ciência. Por outro lado, também representou a oportunidade para políticos angariarem capital simbólico, principalmente em relação a temas considerados 'politicamente corretos', sendo que, entre esses, o da mulher ganhou um lugar de destaque (BOURDIEU, 1987, 1989, 2011)1.

O primeiro país no mundo a iniciar a campanha de vacinação em massa com um imunizante certificado pela sua agência reguladora e recomendada pela OMS foi o Reino Unido, no dia 8 de dezembro de 2020 (BOTTALO, 2020). A personagem escolhida para receber a primeira dose foi uma senhora de 90 anos. A aplicação da vacina também foi atribuída a uma profissional mulher (G1, 2020).

As características da celebração ocorrida no país europeu podem ser percebidas na maioria das 49 nações que iniciaram a imunização ainda em 2020 (AFP, 2020). Em 41 desses locais, a primeira pessoa vacinada era do sexo feminino, o que representa $83,7 \%$ do total (CNN, 2020). O Brasil não figurou nesta lista, vindo a inaugurar a aplicação de imunizantes no dia 17 de janeiro de 2021, imediatamente após o anúncio da Agência Nacional de Vigilância Sanitária (Anvisa) que aprovou o uso emergencial de duas vacinas: uma da Astrazeneca/Universidade de Oxford, elaborada em conjunto com a Fundação Oswaldo Cruz, iniciativa capitaneada pelo Governo Federal; e a Coronavac, do laboratório chinês Sinovac em colaboração com o Instituto Butantan, uma aposta do governo do estado de São Paulo.

Esse ato representa mais um capítulo do embate político travado entre o presidente Jair Bolsonaro (sem partido) e o governador de São Paulo, João Dória (PSDB). Segundo atestam Santos e Fossá (2020), do lado federal, ações administrativas e declarações públicas colocaram em descrédito medidas de contenção da doença, inclusive a vacina; em contraponto, um ator político paulista se colocou a serviço da ciência e como financiador do imunizante brasileiro.

Mesmo com posições antagônicas, o capital político gerado pela primeira aplicação era consenso, já que ambos disputam a preferência do eleitor nas eleições presidenciais de 2022. Na coluna Poder e Contrapoder, André Singer (2020) discute a politização da vacina da covid-19 e constata que "Dória e Bolsonaro estão envolvidos nessa corrida para saber quem vai chegar antes na vacina porque estão, neste momento, depois das eleições municipais, disputando a preferência do público, que não é o conjunto da sociedade, mas uma parte, um público mais conservador" (SINGER, 2020).

Importante destacar que nessa disputa pela vacina o governador de São Paulo saiu na frente. Minutos após a aprovação, sob os holofotes de toda a imprensa brasileira, para além do ato simbólico de vitória, outra representação também se configurava, a exemplo do que se verificou nos demais países: uma mulher foi a escolhida para receber a primeira dose. Chamada a manifestar seu sentimento por se tornar a figura central do momento, a enfermeira Mônica Calazans, de 54 anos, reforçou sua posição como mulher negra, suburbana e que acredita na ciência (ADOMO, 2021).

Isso também ocorreu na maioria dos estados brasileiros, nos quais as primeiras pessoas a serem vacinadas foram mulheres. Das 27 unidades da federação, 26 tiveram como protagonista do ato político uma mulher. Esses números nos levam a analisar o contexto sob a luz da semiótica, podendo trazer imbricações importantes sobre a representação da mulher na sociedade brasileira. Com a intenção de

1 O conceito de capital simbólico aparece na obra de Pierre Bourdieu. No campo político, trata-se de uma espécie de capital de reputação, um capital simbólico ligado à maneira de ser conhecido (BOURDIEU, 2011). 
desvendar as estratégias que residem por trás dessas escolhas, bem como seus efeitos de sentido, realizamos um levantamento empírico sobre os primeiros atos de vacinação junto ao portal de notícias G1, do Grupo Globo. Foram coletadas as coberturas jornalísticas realizadas em cada um dos sites estaduais do grupo de comunicação, resultando em 27 reportagens que foram analisadas para fins deste estudo. As imagens que integram cada um dos textos foram particularmente destacadas nesta análise, a partir do entendimento do valor semântico que possuem ao narrar fatos e provocar sentidos.

\section{GÊNERO, DESIGUALDADES, E SEUS EFEITOS}

Ao tratar de questões relacionadas ao gênero a partir de fenômenos empíricos, apresentamos, em primeiro lugar, conceitos defendidos por autores que trabalham o tema desde a chamada 'Segunda Onda' do feminismo, como a francesa Betty Friedan (1971), que em nível mundial influenciou muitos outros pensadores da mesma linha de pensamento de Simone de Beauvoir; até as novas gerações como Flávia Biroli e Luis Felipe Miguel (2015), Jair Bueno de Araújo e Sylvia Monastérios (2011) em âmbito nacional.

Para Araújo, o conceito gênero "traz à luz os processos da história humana das diferenças biológicas (macho/fêmea)" (ARAÚJO, 2011, p. 3). Todavia, os autores prosseguem desenvolvendo e desvelando como essas diferenças foram sendo enquadradas discursivamente pelas forças de poder. Nesse cenário são naturalizados "corpos biologicamente distintos, impondo, determinando e fazendo prevalecer representatividades de papéis sociais dos corpos sexuados que reproduzirão, historicamente, relações desiguais baseadas nas diferenças percebidas desses corpos marcados por sua biologização" (ARAÚJO, 2011, p. 3).

Durante o período denominado 'Segunda Onda', o movimento feminista não utilizava o termo gênero, mas sim a categoria 'Mulher', entendendo a necessidade de uma identidade que fosse tratada de maneira separada da do 'Homem'. De acordo com Araújo (2011), entendia-se que "todas as mulheres são mulheres por sua condição biológica, logo a cultura masculina se colocava como universal e todas as mulheres, por essa razão, sofreram e continuariam a sofrer as mesmas opressões e dominações de seu sexo oposto" (p. 5). Compreendia-se que, dessa forma, elas ganhavam mais força por fazer parte de "uma mesma categoria e sinergia para a luta contra o opressor, o Homem" (p. 5).

Na publicação ‘Educação, Feminismo e Contracultura: o pensamento de Betty Friedan', os autores Araújo e Monastérios (2011) dialogam com depoimentos da época do pós-segunda guerra. Nessa perspectiva do gênero, os relatos dão conta de que "as mulheres que neste período serviram como mão de obra para o mercado, se viam mais uma vez, a sujeição ao sexo oposto" (p. 51). Quando trabalhavam, assumiam funções inferiores e com salários mais baixos ou então permaneciam na condição de 'rainha do lar', responsáveis pelos serviços domésticos sem prestígio ou remuneração (ARAÚJO; MONASTÉRIOS, 2011, p. 51). Mas, ainda assim, e com todas as lutas, conforme Friedan (1971, p. 305) destacou em sua obra Mística Feminina, elas tentavam buscar "o senso de plenitude, de participação da vida do mundo - não ser uma ilha, e sim parte do continente - e voltavam a ser seres humanos e não apenas donas de casa" (FRIEDAN, 1971, p. 305).

Ainda que Friedan (1971) tenha sido e representado uma das principais pensadoras na atualidade acerca do assunto, suas ideias diziam respeito a um determinado grupo de mulheres, que conforme apontam os estudos de hooks (2015) “são brancas, casadas, com formação universitária de classe média e alta" (p. 193194), não contemplando um todo ou uma interseccionalidade. Em sua publicação denominada Mulheres negras: moldando a Teoria Feminista (HOOKS, 2015), hooks faz críticas à Friedan (1971) mencionando que a feminista "ignorou a existência de todas as mulheres não brancas e das brancas pobres, e não disse aos leitores se era mais gratificante ser empregada, operária [...] do que ser dona de casa da classe abastada" (HOOKS, 2015, p. 194). Para ela, o discurso feminista dominante e praticado por mulheres brancas na contemporaneidade segue a mesma prédica de Friedan (1971), não deixando claro "até que ponto suas 
perspectivas refletem preconceitos de raça e classe, embora tenha havido uma consciência maior sobre esses preconceitos nos últimos anos" (HOOKS, 2015, p. 195).

Outros autores que se opuseram à cultura predominante e desigual se engajaram na causa das mulheres, entre eles a feminista Heleieth Safiotti (2004), que defende a liberdade para as mulheres dos padrões restritivos e coercitivos, conceituados também como patriarcado.

Deve-se levar em consideração, conforme aponta Collins (2000), que gênero, raça e classe social são sistemas distintos de opressão subjacentes a uma única estrutura de dominação. Ademais, é prejudicial estabelecer uma simples comparação entre os sistemas de opressão, diante do risco de hierarquizar as formas de dominação que são intimamente interligadas umas às outras. É nesse sentido que a autora Kimberlé Crenshaw (2002) discute o conceito de interseccionalidade na perspectiva de um problema que busca capturar as consequências estruturais e dinâmicas da interação entre dois ou mais eixos da subordinação. Ela trata singularmente da maneira pela qual o racismo, o patriarcalismo, a opressão de classe e outros tantos sistemas discriminatórios ocasionam desigualdades básicas que estruturam as posições relativas de mulheres, raças, etnias, classes e outras. (CRENSHAW, 2002, p. 177).

A ativista e pesquisadora Leila González (1984) desenvolveu uma abordagem que relaciona raça, gênero e classe para descrever tal relação ou articulação, que se aproxima do conceito de interseccionalidade. Nela, a autora aborda a sociedade brasileira e o mito da democracia racial a partir da imagem da mulher negra, nas quais retrata primeiramente a figura da mulata, na sequência a figura da doméstica e, posteriormente, a figura da mãe preta. Uma das questões centrais que González buscou responder no artigo 'Racismo e sexismo na cultura brasileira' (1984) está relacionada à forma com que a mulher negra é situada no discurso de identificação do dominado com o dominador.

Em suas inferências, Gonzáles (1984) aponta que a mulher negra está entrelaçada nos fenômenos do racismo e sexismo, que por tempos estiveram situados de maneira separada, mas que são frutos de um mecanismo que articula o primeiro como fruto da neurose cultural brasileira, associado a um movimento que produz efeitos violentos sobre a mulher. A autora também reflete sobre a discriminação da mulher negra, atribuindo a divisão racial e sexual do trabalho como geradora de um processo tríplice de discriminação de raça, de classe e de sexo. De acordo com a estudiosa, ser negra e mulher no Brasil "é ser objeto de tripla discriminação, uma vez que os estereótipos gerados pelo racismo e pelo sexismo a colocam no mais baixo nível de opressão". (GONZÁLES, 1981, p. 44).

Já Flávia Biroli e Luis Felipe Miguel (2015) refletem no artigo ‘Gênero, raça, classe: opressões cruzadas e convergências na reprodução das desigualdades' alguns conceitos vistos sob um viés mais voltado à mulher negra. Segundo eles, as discussões do marxismo que contrariavam os ideais e dominação capitalista defendiam a luta de classes, no entanto, não se concentravam nos aspectos da problemática de gênero, tampouco da raça. "O esquecimento de tal pauta, levava, à uma naturalização e exploração das mulheres" (p. 31). As negras foram a maior parte do público feminino explorado, porque essa relação de desigualdade não é só de gênero, mas também de raça e de classe social, na qual se legitima as 'fragilidades' e reitera-se papéis sociais.

No cenário contemporâneo brasileiro ainda persiste um forte vínculo entre raça e classes em contextos de pobreza. Mesmo depois de 132 anos da abolição da escravatura no Brasil, o negro tem ocupado posição desigual em relação aos brancos no âmbito profissional. Para Lima (2012), faz-se necessário implementar um debate sobre as desigualdades sociais, em especial as raciais. As desigualdades, segundo a autora, não podem ser entendidas a partir de um plano de capacidades e desempenhos individuais, mas sim de uma análise completa da conjuntura que levou à distinção de categorias de pessoas socialmente diferentes. A passagem do trabalho escravo para o trabalho formalmente livre "manteve todas as virtualidades do escravismo na nova situação" (SOUZA, 2017, p. 102). 
Ianni parte da hipótese de que existe uma doutrina de inferiorização dos negros, que conta com inúmeros instrumentos para sua propagação e que ainda mantém por objetivo a manutenção das estruturas constituídas nos anos de escravidão:

\begin{abstract}
[...] a doutrina da inferioridade do mestiço, do negro e do índio convinha à camada dominante na sociedade brasileira, interessada na manutenção do status quo. Ela opera em benefício dos que dominam as organizações e os instrumentos de mando. Trata-se de preservar estruturas constituídas, em detrimento de mudanças sociais. No caso do negro, a própria situação existente nasce, em larga parte, do fato da desigualdade racial ser percebida, explicada e aceita socialmente como algo natural, justo e inevitável, como se a ordem social competitiva não alterasse o antigo padrão de relação entre o negro e o branco. A única fonte dinâmica de influência corretiva irrefreável vem a ser, portanto, a própria expansão da ordem social competitiva. Assim, as representações ideológicas surgem nitidamente como técnicas de dominação, ou seja, de preservação de estruturas estabelecidas (IANNI, 1972, p. 206).
\end{abstract}

Nesse sentido, as questões raciais são as principais responsáveis por manter as relações de poder na sociedade brasileira e atuam como condicionantes da pobreza e da falta de acesso da população negra, em especial as mulheres, sobre as quais pesam também os preconceitos de gênero.

Entre o final do século XIX e o início do século XX, quando mulheres de classe média brancas lutavam pelo direito ao voto e ampliação de oportunidades na educação, as mulheres negras ainda se deparavam com reivindicações em torno da abolição da escravidão. Nesse sentido, o registro em países como o Brasil, locais onde a abolição da escravatura ocorreu apenas na segunda metade do século XIX, e que a distinção não se efetiva apenas no plano do gênero feminino e masculino, mas também entre mulheres de diferentes classes, cores e etnias.

\title{
METODOLOGIA E SELEÇÃO DE AMOSTRA PARA ANÁLISE
}

O corpus de análise deste estudo foi constituído a partir da visita em cada um dos 26 portais G1 em todos os estados, mais o Distrito Federal, entre os dias 17 e 21 de janeiro de 2021, totalizando 27 reportagens. O recorte temporal compreende o período em que os governos estaduais promoveram solenidades para marcar o início da campanha de vacinação. Vale destacar que todos os textos foram manchetes ${ }^{2}$ no dia de sua veiculação em seus respectivos portais.

A escolha do objeto se deu por conta do seu acesso gratuito, sem a necessidade de assinatura para obter as notícias. Além disso, sua arquitetura midiática bastante capilarizada por todo o país com sites estaduais - assim como se verifica na TV Globo e suas afiliadas - permite uma análise de conteúdos que seguem a mesma linha editorial e padronização de redação de textos e edição de imagens.

Um banco de dados foi construído contendo o título das publicações, a linha-fina ${ }^{3} \mathrm{e}$ os dados das pessoas escolhidas para receberem a primeira dose dos imunizantes (nome, idade, sexo e profissão). Além dessas informações, a foto principal que ilustra a reportagem também foi coletada por meio da técnica de captura de tela (print screens).

Para entender o material coletado, utilizamos como metodologia a análise do discurso e os conceitos de semiótica plástica e figurativa (GREIMAS, 1984; GREIMAS; COURTÉS, 2008), focando, em particular, nos processos de homologações entre as isotopias plástico-figurativas e temáticas presentes nas imagens. A este propósito, cabe ressaltar que, de acordo com Greimas, uma isotopia temática é a reiteração, ao longo de uma determinada narrativa, de valores semânticos específicos, os quais, por sua vez, estão manifestados por figuras e/ou formantes plásticos do plano da expressão (DEMURU, 2020, p. 211).

2 Jargão jornalístico que significa título principal, de maior destaque, no alto da primeira página de jornal, revista ou site de notícias, alusivo à mais importante dentre as informações contidas na edição.

3 No jargão jornalístico, refere-se a um pequeno texto abaixo do título que complementa e pode também ampliar as informações. 
As figuras são os elementos do mundo reconhecíveis e nomináveis, cujo sentido é válido apenas no universo sociocultural onde estão inseridas, como, por exemplo, o corpo masculino, o corpo feminino, a câmera, a lente, a agulha, a seringa e assim por diante (GREIMAS, 1984). Os formantes plásticos são os traços eidéticos (curvos vs. reto, redondo vs. quadrado etc.), cromáticos (vermelho vs. azul, branco vs. preto, saturado vs. não saturados etc.), topológicos (alto vs. baixo, englobante vs. englobado, esquerda vs. direita). Tanto as figuras, quanto os formantes plásticos constroem e dão corpo ao sentido da imagem, estabelecendo correlações entre os dois planos da linguagem, neste caso, a verbal e visual (DEMURU, 2020, p. 211-212).

Por outro lado, o conceito de isotopia indica a iteratividade e a recorrência de um ou mais traços distintivos, seja do plano da expressão, seja do plano do conteúdo, garantindo, assim, a coerência e a homogeneidade do texto. São três tipos: as isotopias temáticas, que reiteram valores semânticos (a vida, a morte, a saúde, a doença etc.); as isotopias figurativas, que tangem à repetição de uma ou mais figuras (a cruz, o caixão, o sol, a árvore, a pomba etc.); e as isotopias plásticas, que insistem na reprodução de determinados traços cromáticos (verde, amarelo, rosa, azul etc.) e topológicos (alto, baixo, esquerda, direita, no centro etc.). Vale destacar que uma isotopia figurativa ou uma isotopia plástica podem sustentar (figurativa ou plasticamente) uma isotopia temática (a saúde, a resistência etc.), contribuindo, dessa forma, para a manifestação de valores semânticos profundos inscritos e diluídos no texto (DEMURU; GARCIA, 2020, p. 89-90).

Os valores semânticos profundos manifestados por traços ou isotopias figurativas e/ou plásticas podem ser dispostos - conforme o corpus analisado - ao longo dos polos que constituem aquilo que Greimas define "categoria tímica" (GREIMAS; COURTÉS, 2008, p. 505). Em consonância com o significado do termo 'timia', trata-se do 'humor' e do 'tom afetivo' associado a um determinado semantismo. No tocante à 'timia', esta articula-se em 'euforia' e 'disforia', podendo conotar um traço semântico como 'eufórico' e outro como 'disfórico', provocando, desta forma, a sua valorização em termos positivos e/ou negativos (GREIMAS; COURTÉS, 2008, p. 505). Essas definições iluminam a descrição do corpus estudado.

Nossa hipótese preliminar é que a articulação entre a linguagem verbal e imagética dos portais revela: (i) a imagem da mulher como sujeito social 'frágil' e 'dependente', o qual precisa do homem para 'sobreviver' e 'existir'; (ii) a visão do Estado 'Pai-Provedor', figurativizado enquanto 'homem forte', que sabe e pode proporcionar o 'bem-estar' individual e coletivo, em particular o da mulher; e (iii) o uso de mulheres representativas de 'minorias' que remetem a uma ideia de um Brasil diverso e miscigenado, usado para reforçar a imagem dos políticos-homens como sujeitos moral e politicamente corretos.

\section{A mulher enquanto sexo 'frágil'}

O primeiro semantismo conferido à mulher que emerge da investigação do corpus recortado é o da 'fragilidade', o que já é identificado em uma análise preliminar ao se verificar dados quantitativos da vacinação. Em 26 das 27 unidades federativas brasileiras, as primeiras pessoas ou profissionais do grupo de risco vacinadas foram mulheres.

Por trás das aparências, o discurso das manchetes constrói a mulher enquanto um sujeito - e um 'sexo' 'fraco', 'débil', em uma palavra, 'frágil'. Dentro do quadro narrativo elaborado pelo site, assim como naquele dos governos, a fragilidade assume um sentido ‘disfórico', visto que representa alguém que está "desprovido de força", "autonomia", "potencial" (GREIMAS; COURTÉS, 2008, p. 149), atributos que remetem à ideia de virilidade como qualificação atribuída apenas aos homens, de acordo com os valores dominantes da sociedade patriarcal.

Esse distanciamento revela marcas originadas em questões de gênero ainda não resolvidas, que continuam, por meio de discursos diversos, a colocar a mulher numa situação de vulnerabilidade. 
Nesse contexto, cabe ressaltar que a primeira candidata a ser vacinada no país foi uma mulher preta, moradora do estado de São Paulo. Como dissemos anteriormente, o ato mostrou-se carregado de simbolismos, tanto pelo feito político do governador paulista, antagonista do governo federal na guerra das vacinas, quanto pela representatividade da pessoa escolhida para protagonizar a cena. Chamada a manifestar seu sentimento por se tornar a figura central do momento, a enfermeira Mônica Calazans, de 54 anos, reforçou sua posição como mulher preta, suburbana e que acredita na ciência (ADOMO, 2021) (Figura 1).

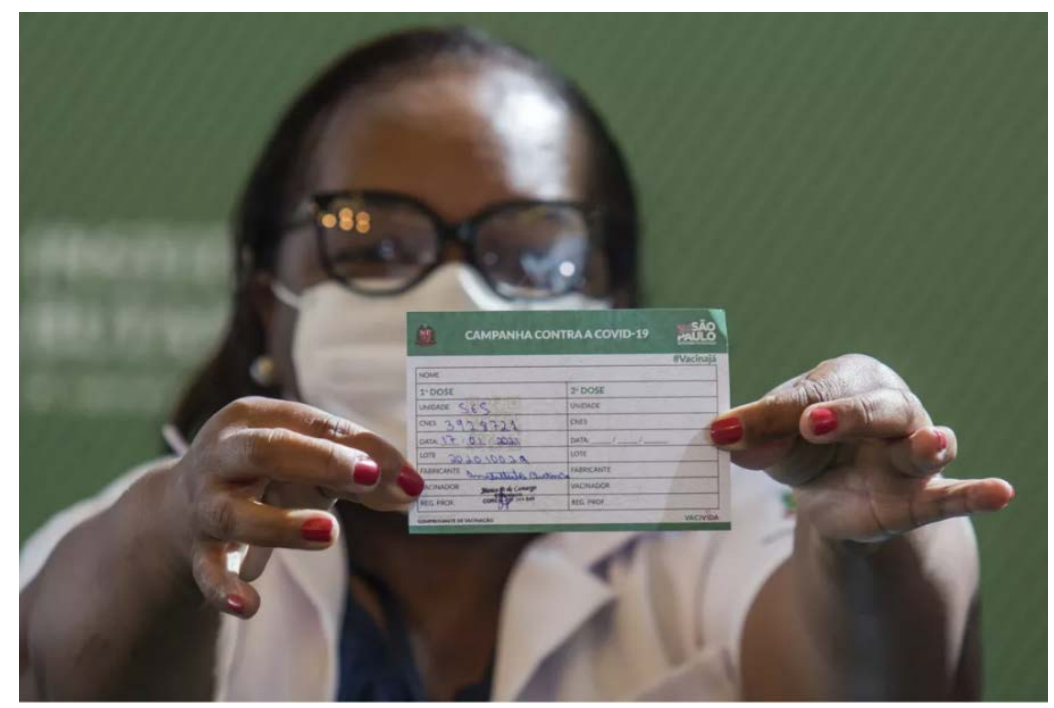

Figura 1 - Primeira pessoa a ser vacinada no Brasil Fonte: Rodrigues, 2021.

Tal ação também é outro fator a ser considerado quando se verifica a sua repetição na maioria dos estados brasileiros. A Tabela 1 aponta a divisão de mulheres vacinadas por raça ${ }^{4}$ no país, considerando a classificação do Instituto Brasileiro de Geografia e Estatística (IBGE).

\section{Tabela 1 - Divisão de mulheres vacinadas por raça}

\begin{tabular}{lcc} 
Raça & Quantidade & Porcentagem \\
Preta & 16 & $61,6 \%$ \\
Parda & 4 & $15,4 \%$ \\
Indígena $^{5}$ & 3 & $11,5 \%$ \\
Branca & 3 & $11,5 \%$ \\
Amarela & 0 & $0 \%$ \\
\hline
\end{tabular}

Fonte: elaboração dos autores.

Os dados estatísticos apontam para maior abrangência nas imagens de mulheres pretas e pardas, que unidas somam $77 \%$ das primeiras vacinadas, em detrimento de $11,5 \%$ da população branca e $11,5 \%$ de indígenas. No item representatividade, as reportagens mencionaram a categoria profissional ocupada pelas mulheres, segundo aponta a Tabela 2.

4 A tabela foi criada com base no acordo com traços fenotípicos estabelecidos pelo IBGE e identificados nas fotos que ilustram as reportagens.

5 Há uma diferença com relação ao número de mulheres indígenas vacinadas, pois no estado do Amazonas a mulher vacinada é profissional de saúde e da raça indígena. 
Tabela 2 - Mulheres vacinadas

\begin{tabular}{lcc} 
Representatividade & Quantidade & Porcentagem \\
\hline Profissionais de saúde & 21 & $80,8 \%$ \\
Idosas institucionalizadas & 3 & $11,5 \%$ \\
Indígenas & 2 & $7,7 \%$ \\
\hline
\end{tabular}

Fonte: Elaboração dos autores

Também se identifica maior prevalência de profissionais da saúde, com 80,8\% das mulheres vacinadas, item facilmente justificado pelo fato de a categoria possuir prioridade no calendário de vacinação dos estados. No âmbito do tipo de ocupação, a tabela 3 aponta que técnicas de enfermagem e enfermeiras representaram um maior número, com 90,4\% do total de vacinadas.

\section{Tabela 3 - Tipos de profissionais de saúde vacinadas (de um total de 21)}

\begin{tabular}{lcc} 
Profissão & Quantidade & Porcentagem \\
\hline Técnica de enfermagem & 10 & $47,6 \%$ \\
Enfermeira & 9 & $42,8 \%$ \\
Assistente Social & 1 & $4,8 \%$ \\
Médica & 1 & $4,8 \%$ \\
\hline
\end{tabular}

Fonte: elaboração dos autores.

Todas essas situações apresentadas foram exploradas de formas distintas, principalmente por parte do discurso político-institucional. Os personagens políticos, aproveitando-se da narrativa da fragilidade, construíram a própria imagem de um Estado 'paterno', 'provedor' e 'protetor', que acolhe todos, em especial aqueles mais frágeis, levando-se em consideração um Brasil diverso e miscigenado, que abarca todas as representatividades. Tais simbolismos nos importam em particular para efeitos desta análise, ao considerálos parte fundamental no fluxo da engrenagem da produção midiática, como um de seu mecanismo testemunhal que revela aos leitores os acontecimentos colhidos no exato momento em que estes acontecem, de acordo com os preceitos do fotojornalismo formulados por Niklas Luhmann (2005).

Segundo o autor, o papel do fotojornalismo está alicerçado no conjunto da esfera midiática da difusão organizada de informação a partir de um sistema orientado por uma lógica própria, que mantém relação com outros sistemas sociais (o político, o econômico, o artístico, o direito) e são entendidos como galáxias de comunicação - amplas, socialmente necessárias e reguladas por códigos próprios.

O critério maior utilizado pelo sistema midiático é aquilo que é passível de ser informado, sendo capaz de causar, no tecido social, certa polêmica, de provocá-lo, movê-lo, 'irritá-lo'.

Os meios de comunicação mantêm, pode-se dizer assim, a sociedade em vigília, desperta. Produzem uma sempre renovada disposição para contar com a surpresa, com o irritante. Daí que os meios massivos se ajustem à dinâmica acelerada própria de outros sistemas de funções como a economia, a ciência, e a política, que estão permanentemente confrontando a sociedade com novos problemas (LUHMANN, 2005, p. 35).

Reconhecendo que o fotojornalismo é linguagem, e que, portanto, cumpre exigências próprias da comunicação humana, quais são os elementos que estruturam a produção de seus sentidos? Kossoy (1999), em seu livro Realidades e ficções na trama fotográfica, já aponta para essa diversidade de discursos 
implícitos numa imagem, enfocando as condições históricas e sociais que marcam os significados da fotografia. Para ele,

a realidade da fotografia não corresponde (necessariamente) à verdade histórica, apenas ao registro expressivo da aparência. (...) A realidade da fotografia reside nas múltiplas interpretações, nas diferentes leituras que cada receptor faz dela num dado momento, tratamos, pois, de uma expressão peculiar que suscita inúmeras interpretações (KOSSOY, 1999, p. 37-38).

Existe na imagem uma mensagem simbólica vinculada à sociedade, à história e à ideologia de quem a produz e de quem a vê, o que retrata um universo simbólico, favorecendo a construção de significados, conhecimentos e valores, cuja diversidade de temas oferece espaço para a reorganização e construção de conceitos.

Desse modo, partimos de uma perspectiva do fotojornalismo como uma atividade social que envolve estruturas e discursos em contextos específicos, cumprindo funções representacionais, interacionais e composicionais.

\begin{abstract}
a dimensão representacional tem a ver com o conteúdo das imagens e com seus efeitos em termos de conhecimento e de crenças; a interacional tem a ver com as relações sociais que são ativadas através da imagem visual e com os seus efeitos, em termos de poder e de controle; e a dimensão composicional relaciona-se com o modo como os elementos representados formam um todo coerente (PINTO-COELHO; MOTA-RIBEIRO, 2007, p. 86).
\end{abstract}

Essas percepções contribuirão para a leitura das relações entre fatos narrados e elementos representados das imagens nas análises a seguir.

\title{
A visão do Estado como 'Pai-Provedor'
}

Tratamos agora da construção e figurativização do 'homem forte', como Pai-Provedor, que sabe e pode proporcionar o 'bem-estar' individual e coletivo, em particular o da mulher. Se na esfera patriarcal, este sujeito apresenta determinadas características (BIROLI, MIGUEL, 2015; SAFFIOTI, 2011), na pública, ele é dotado e investido de poder, não apenas aquele conferido de forma eletiva ou segundo articulações políticas, mas na qualidade de um indivíduo que age de acordo com as práticas previstas por lei a um profissional de medicina.

A metodologia proposta para a descrição das imagens utiliza os conceitos de Greimas com base na obra Semiótica Plástica e Figurativa (1984). Nesta, o semioticista trabalhou categorias de análise de figuras chamando-as topológica, cromática e eidética, entre outras. Elas representam pela ordem: posições (baixo, alto, central, periférico, superior e inferior), as cores (preto, branco, amarelo, verde, azul, vermelho) e formas (curva, reta, circular).

Na imagem abaixo (Figura 2), vemos a primeira cidadã, uma mulher preta e enfermeira, em Salvador, sendo imunizada pelo secretário de saúde da Bahia, Fábio Vilas-Boas, que é médico e tem um cargo relevante na esfera estadual - duas posições elevadas socialmente, diferindo em tudo nesses aspectos apontados em relação à candidata a tomar a dose inicial da vacina. Assim, usando dessa autoridade do 'saber', ele 'pode' aplicar a vacina, garantindo sobre si próprio os holofotes neste momento. 


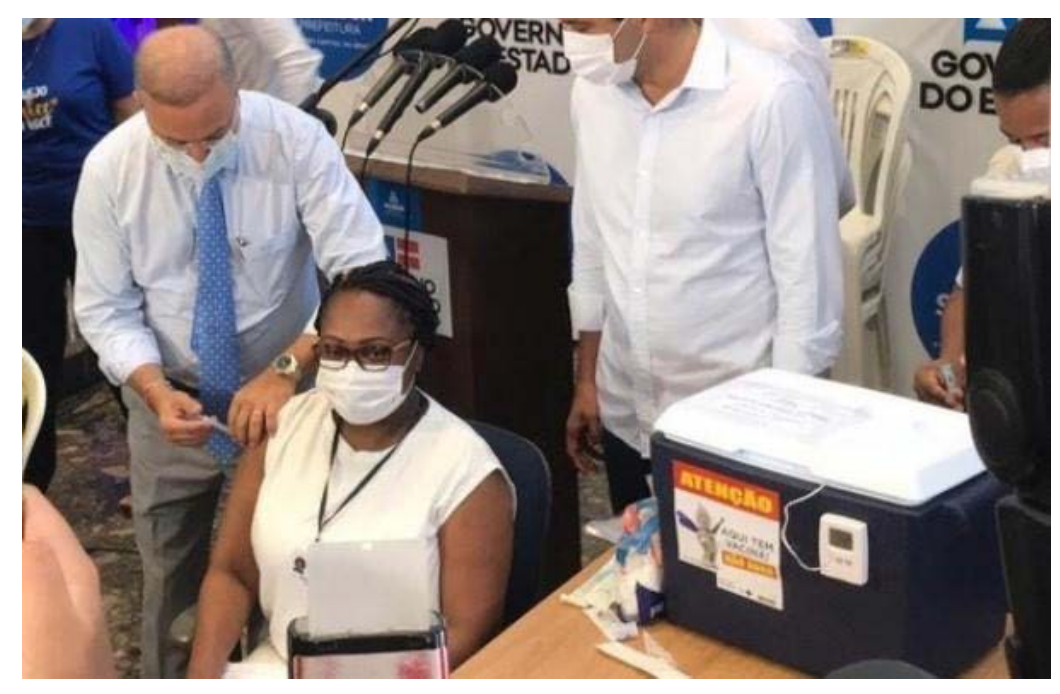

Figura 2 - Enfermeira em Salvador toma a vacina Fonte: G1 BA, 2021.

Em uma estratégia parecida, o governador de Goiás, Ronaldo Caiado (Figura 3), que também é médico, usa a ocasião para realizar o primeiro procedimento de imunização contra a covid-19 em uma moradora de um abrigo de Goiânia passando a imagem de Pai-Provedor como abordado no início deste tópico: daquele que está 'presente', 'preocupado' em garantir os direitos e as necessidades das mulheres. Outra categoria identificada na descrição das Figuras 1 e 2 é a eidética, ou seja, quando o político aparece em pé curvado no centro da foto e junto a outros sujeitos, que a cercam. $\mathrm{O}$ ato pode simbolizar uma espécie de abraço reforçando a ideia de proteção. A única semelhança visível entre o agente que aplica a vacina (Figura 2), outros personagens e a mulher é a camiseta que vestem destacando o slogan da campanha 'Vacinar salva vidas'. Esse mesmo lema aparece no alto ao fundo acima da bandeira do estado de Goiás.

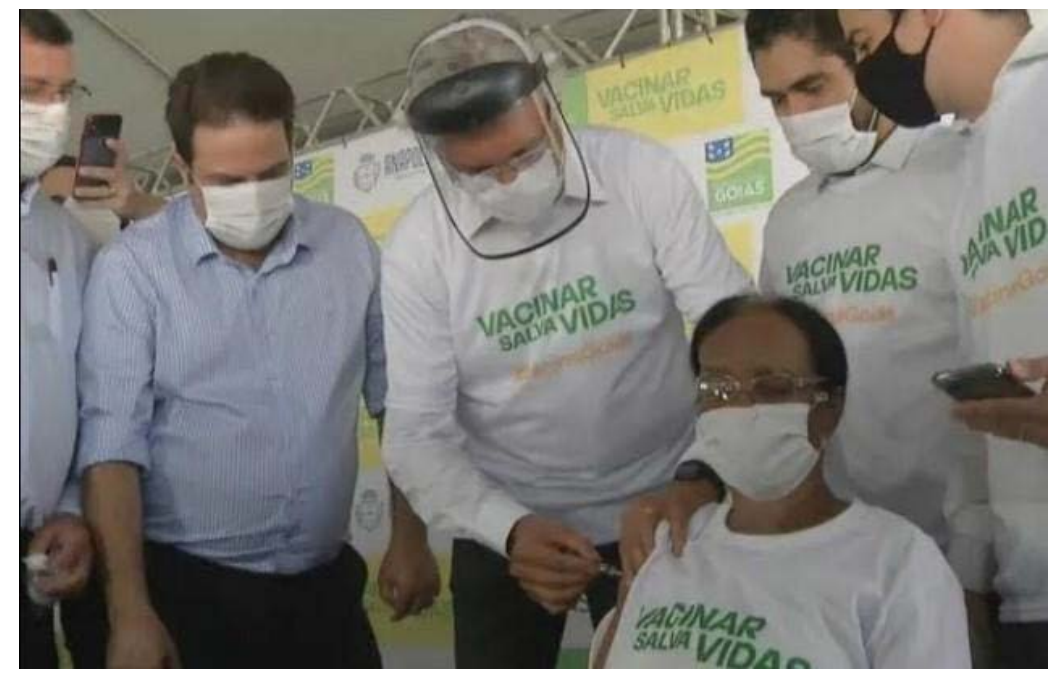

Figura 3 - Primeira moradora de abrigo vacinada em Goiânia Fonte: Santana, 2021.

O arranjo topológico das imagens acima evidencia um contraste entre duas posições específicas: a oposição ‘alto’ vs. 'baixo'. No alto, estão os homens, com destaque para o governador, ao centro, responsável pela aplicação da vacina. Embaixo, sentada, desponta a mulher, em cujo corpo debruçam-se os homens. Ganha forma, assim, por meio desta configuração plástica, uma relação semissimbólica (GREIMAS, 1984), que homologa a oposição 'alto' vs, ‘baixo', no plano da expressão, com as oposições ‘fortes' vs. 'frágil' e 
'Cuidador' vs, 'Assistida'. Mais do que isso: em meio à cena (Figura 2), a palavra 'atenção' na caixa da vacina, em amarelo e vermelho, fortalece o conceito de superioridade nas relações concernentes ao campo político e de gênero. Sob outra ótica, pode-se chamar a ideia anterior de atendimento 'prioritário' à mulher. Essa disposição topológica traz à tona e reforça o papel temático do homem 'pai' e 'provedor'. O homem, que também é o Estado, coloca a mulher em posição de inferioridade, considerando-a fraca como sujeito que precisa ser 'protegido', não podendo se virar sozinho. Ele usa a mulher e a imagem da mulher preta ('minoria' da 'minoria') para criar uma aura de homem ético, moralmente e socialmente engajado, que conhece a "realidade” do Brasil. É esse homem que 'pode' e 'sabe' resolver.

Nas próximas imagens a serem analisadas, temos outros actantes, dessa vez, destituídos do 'saber' do político que é médico, mas não do 'poder' que tem como homem nos cargos públicos conquistados nas eleições e também na sociedade. No evento no Palácio dos Leões no Maranhão (Figura 4), de acordo com a notícia 'Vacinação contra a covid-19 começa no Maranhão com cinco imunizados', mais do que um maranhense recebe a primeira dose da vacina nesta ocasião, entre eles uma técnica de enfermagem, como vemos na foto divulgada pelo Portal G1. Não por acaso, segundo as hipóteses e dados levantados no corpus desta pesquisa, é uma mulher-preta que parece não se sentir muito à vontade com o espetáculo que se tornou esse momento inicial de vacinação do país, fato evidenciado pelo jeito tímido e a forma com que sustenta os braços sobre as pernas. Ela está situada ao centro entre púlpitos maiores que sua altura sentada que foram usados para os discursos da proteção que o Estado está provendo. Nesta posição, que literal e figurativamente mostra a mulher abaixo das demais autoridades políticas e da saúde do Estado, a sensação que ela transmite é de desconforto diante das câmeras, enquanto em pé ao seu redor - do lado esquerdo superior e à frente dos dizeres na placa 'Maranhão contra o coronavírus' - o governador Flávio Dino aplaude a ação reforçando o 'olhar atento’ que é dado à saúde no Estado que governa.

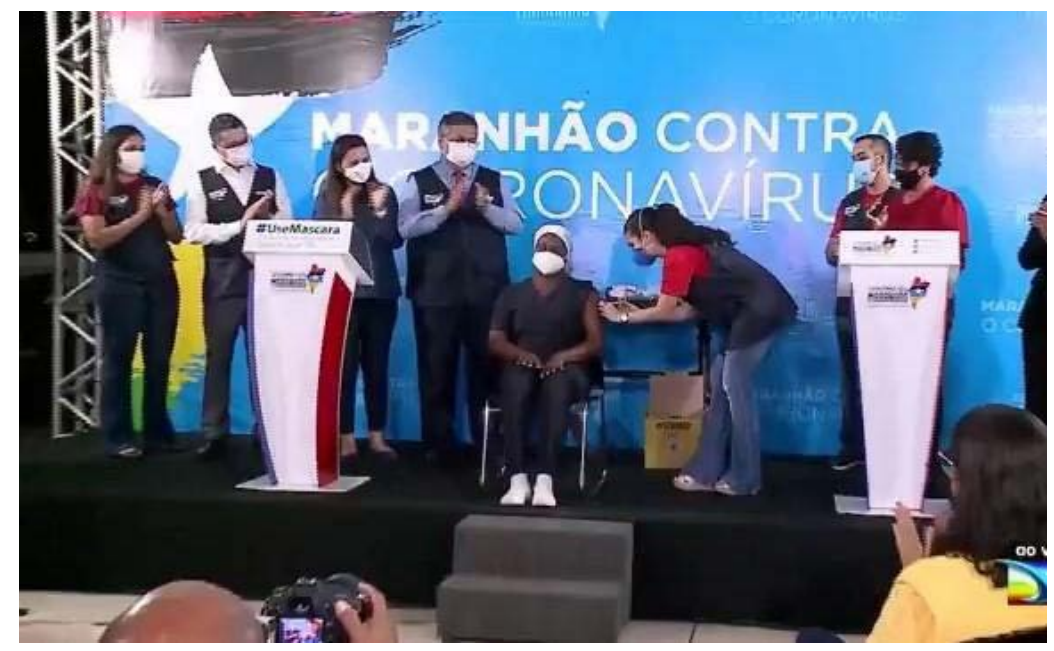

Figura 4 - Técnica de enfermagem vacinada no Maranhão Fonte: Cardoso, 2021.

Outra técnica de enfermagem (Figura 5) representou os trabalhadores da linha de frente no combate da pandemia no Mato Grosso, sendo primeiramente imunizada. Do seu lado superior direito estão o governador Mauro Mendes, a primeira-dama Virginia Mendes e o secretário de Saúde, Gilberto Figueiredo, entre outras autoridades. Como um pai-provedor que 'cuida', o homem público abaixa um pouco a cabeça e encurva o corpo na tentativa de confirmar que o procedimento está sendo feito. $\mathrm{O}$ encurvar-se também pode transmitir a ideia de 'proximidade' com a vacinada. Enquanto ele se posiciona dessa maneira, a mulher que recebeu a primeira dose de outra profissional mulher-preta olha para frente em direção ao equipamento 
fotográfico que registra o ato. Atrás está um backdrop montado no palco consolidando a imagem de que o Estado cumpre com seu papel.

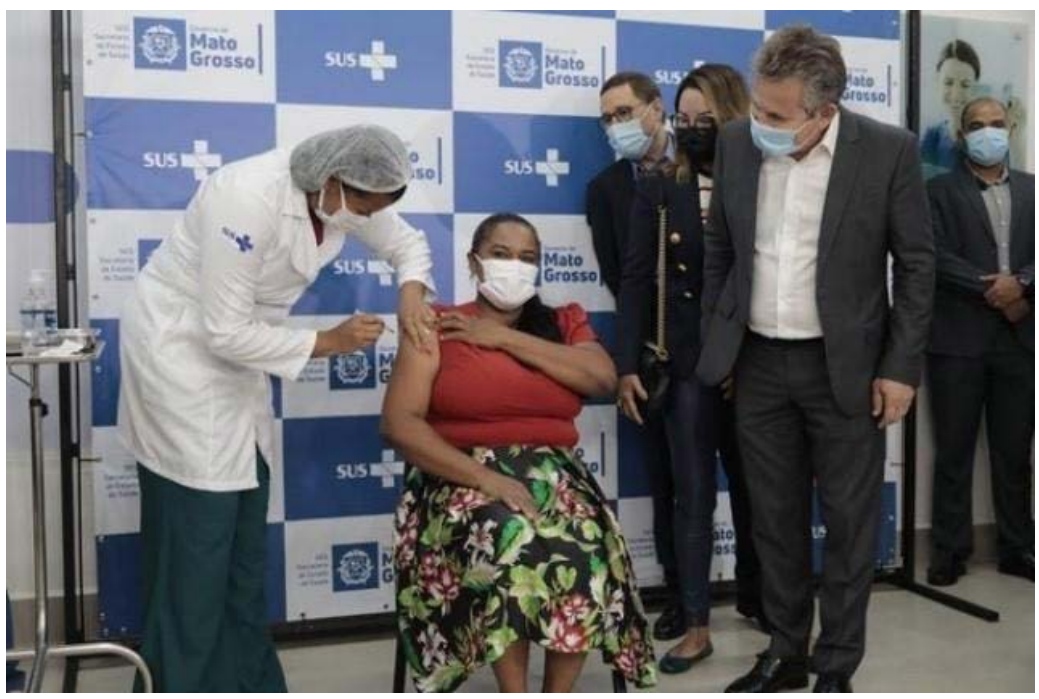

Figura 5 - Primeira profissional de saúde recebe vacina no Mato Grosso Fontes: Borges, 2021.

Na Figura 6, vemos a primeira enfermeira em Belém ser imunizada. Nesta imagem observamos o termo 'vacina' como uma recorrência ou isotopia (GREIMAS; COURTÉS, 2008, p. 275) em diversos momentos: no painel atrás dos sujeitos que aparecem em ação e na camiseta vestida pelo governador Helder Barbalho com a hashtag 'bora vacinar'. Sem dúvida, essa descrição acompanhada de tais elementos apontados reforçam a ideia da participação do Estado como aquele que 'protege' seus cidadãos. Fazendo uma relação com a imagem anterior (Figura 5), ele se encontra na mesma posição e postura do governador de Mato Grosso, voltado para a mulher vacinada, que olha em outra direção.

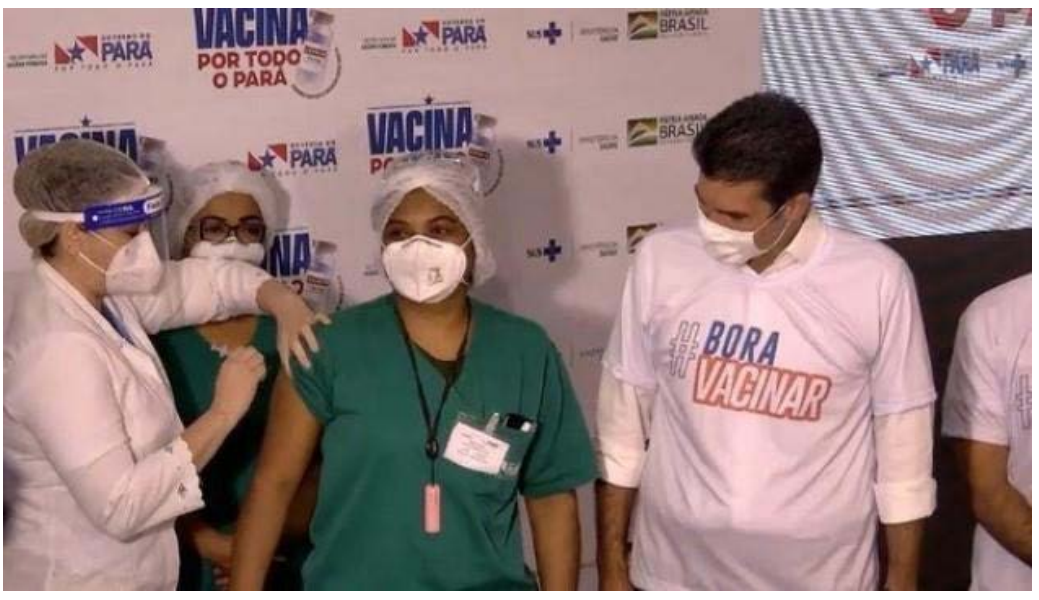

Figura 6 - Primeira enfermeira imunizada no Pará

Fonte: França, 2021.

Na imagem seguinte (Figura 7) vemos o governador de Pernambuco Paulo Câmara (PSB), a vicegovernadora Luciana Santos (PCdoB), além do secretário de saúde, André Longo acompanhando a primeira dose da vacina ser ministrada. Ele está ao centro ao lado de outras lideranças políticas aplaudindo o momento em que a idosa institucionalizada no Estado recebe a vacina, sentada fitando o chão. 


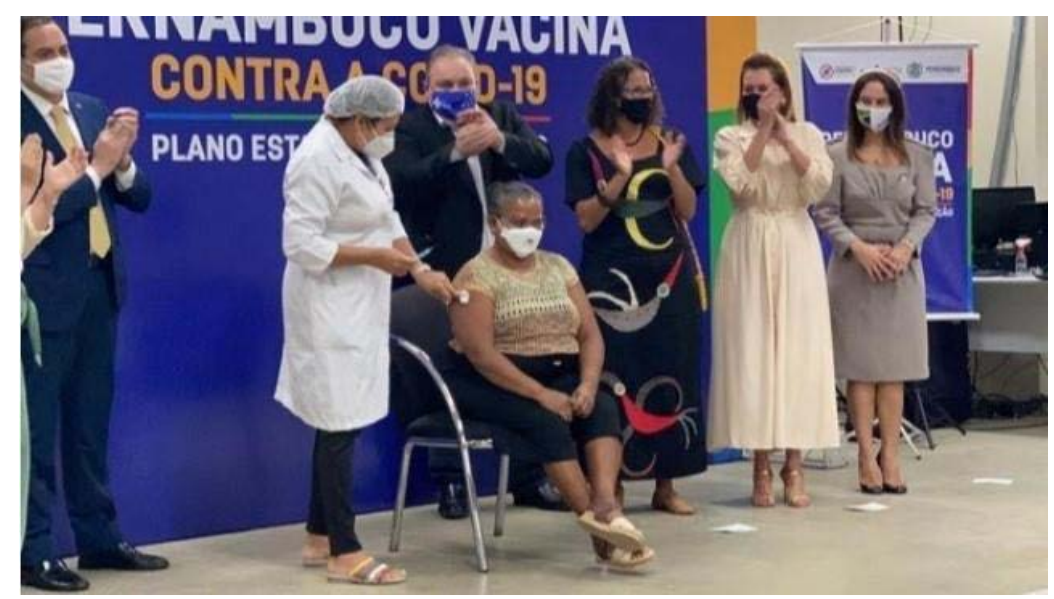

Figura 7 - Primeira moradora de abrigo vacinada em Pernambuco Fonte: Alves, 2021.

A tendência à manipulação não foge à regra e, neste caso, os homens da política se apropriam do sujeito 'fraco' para se fazerem 'fortes' e evidentes. Possivelmente na expectativa de que essa imagem seja lembrada nos próximos processos eleitorais. Manipular, de acordo com Greimas e Courtés (2008, p. 300), "caracteriza-se como uma ação do homem sobre outros homens, visando a fazê-los executar um programa dado; no primeiro caso, trata-se de um 'fazer-ser', no segundo, de um 'fazer-fazer”". A citação "outros homens" (p. 300) também diz respeito às mulheres. As recorrências textuais e imagéticas como estar 'em pé' (alto/superior), sentada (baixo/inferior), e o preto-branco atestam e reafirmam em cada figura analisada tal problemática da inferiorização da mulher. Adiante desvendaremos as análises com ênfase nas minorias.

\section{A mulher representante das 'minorias'}

Este tópico focará a análise das mulheres como representantes das 'minorias', de acordo com os achados no corpus. Esse termo 'minorias' abre um leque de possibilidades para várias discussões no âmbito acadêmico justamente porque muitas vezes é usado de maneira corriqueira no cotidiano ou no 'mundo natural', significando para Greimas e Courtés (2008, p. 324) o mesmo que o 'mundo do senso comum', ou seja, a visão de mundo que influencia e molda comportamentos. Importante relacionar essa a outras temáticas, que num contexto podem facilitar a compreensão deste dado empírico e de suas implicações numa sociedade. Assim sendo, nos concentramos em mostrar como isso ocorre no mundo natural, onde as mulheres são tidas como minorias. E, quando se trata de pretas, o preconceito social é muito maior por se encontrar "em uma minoria que sofria por participar de outra minoria que, no caso em tela, consiste em ser uma mulher negra" (PORDEUS; VIANA, 2021, p. 119). Avaliando semioticamente e de acordo com os apontamentos até aqui feitos, a mulher é tratada como algo ou alguém 'pequeno', sem importância. Se buscarmos o sentido literal no dicionário, o conceito de minoria é "subgrupo religioso, social, étnico, cultural, racial que, numa sociedade, é considerado inferior ou diferente do grupo maior (maioria), sendo por ele discriminado, não possuindo seus mesmos direitos ou oportunidades" (MINORIA, 2009). O contraditório é que se levarmos em conta o relatório da Organização das Nações Unidas (ONU, 2020), convergindo com o objeto de análise, 70\% das profissionais que trabalham nesta área são mulheres, dado também confirmado por meio da Pesquisa Nacional de Amostra por Domicílios (PNAD Contínua) feita pelo Instituto Brasileiro de Geografia e Estatística (IBGE) e divulgada pela Agência IBGE (SARAIVA; BELLO; RENAUX 2018). O mesmo levantamento também mostra que "a participação das mulheres supera a dos homens em algumas profissões culturalmente identificadas como "femininas"' (SARAIVA; BELLO; RENAUX, 2018). O estudo reforça que "a maior disparidade é encontrada na categoria dos empregados domésticos, na qual 92,3\% são 
mulheres [...] Elas também predominam no magistério, nas enfermarias e na assistência social” (SARAIVA, BELLO e RENAUX 2018). Todas são profissões que implicitamente estão atreladas à ideia de que o 'cuidado do outro’ é incumbência da mulher (SARAIVA; BELLO; RENAUX, 2018).

Além destes índices, a população brasileira é composta 51,8\% por mulheres, ou seja, nesse quesito também o número é superior ao de cidadãos homens (SARAIVA; BELLO; RENAUX, 2018). Nesse sentido, as imagens comprovam tais números já que a maioria daqueles que aplicam a vacina e a recebem são mulheres.

Retomando a ideia inicial, nesse ponto do estudo nos concentraremos em mostrar como as mulheres representantes das minorias são figurativizadas, seguindo a mesma metodologia e conceitos propostos por Greimas (1984). Nas figuras abaixo (8 e 9), as primeiras mulheres imunizadas no Amapá e Espírito Santo encontram-se, topologicamente, numa posição de centralidade. Trata-se de um lugar oposto ao que elas ocupam no cotidiano. As personagens nas Figuras 8 e 9 são profissionais da área da saúde idosas. Em ambas as imagens, os homens no canto direito, cortados pela lente que captou os eventos, parecem 'supervisionar' o trabalho. Corrobora com a descrição deste tópico que aqui não foi tão evidenciada a figura dos governantes como nas primeiras análises. As cores predominantes na Figura 8 são o verde, amarelo, branco e azul no painel ao fundo. As bandeiras de alguns municípios do Estado do Amapá também remetem à cromática da bandeira brasileira, atrelado ao pensamento de que a nação e suas unidades da federação são cumpridoras do programa de imunização, embora tenhamos acompanhado a morosidade no processo e os desdobramentos neste período de pandemia.

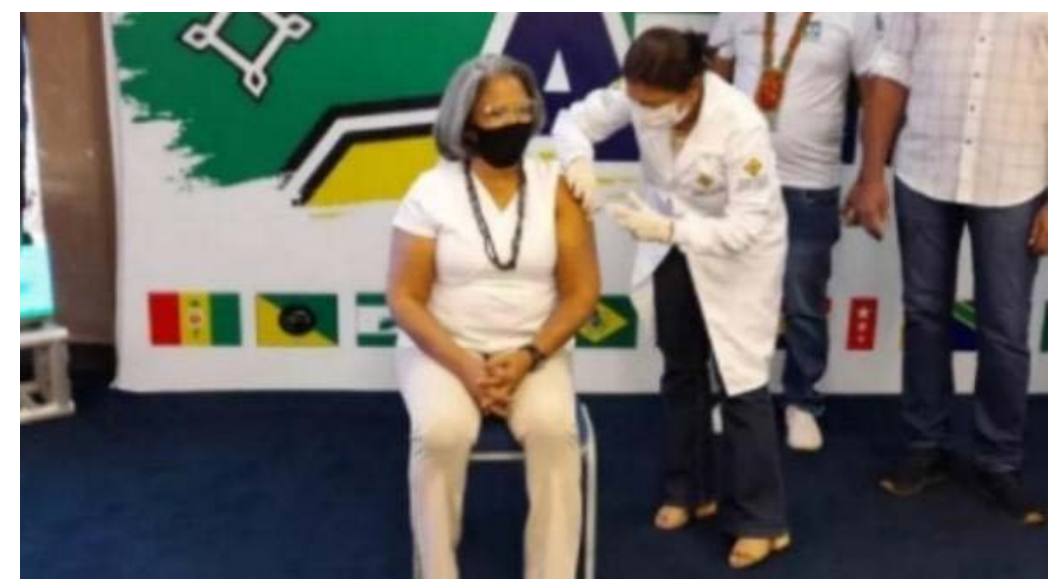

Figura 8 - Técnica de enfermagem vacinada no Amapá Fonte: Pacheco e Vidigal, 2021.

Já na Figura 9 observamos a cromática rosa na parede por detrás da candidata vacinada, reforçando o padrão de cor que, no universo do senso comum, é destinado à mulher. Tais imagens refletem os mecanismos de manutenção de um padrão seguido das imposições impostas a 'grupos inferiores'. 


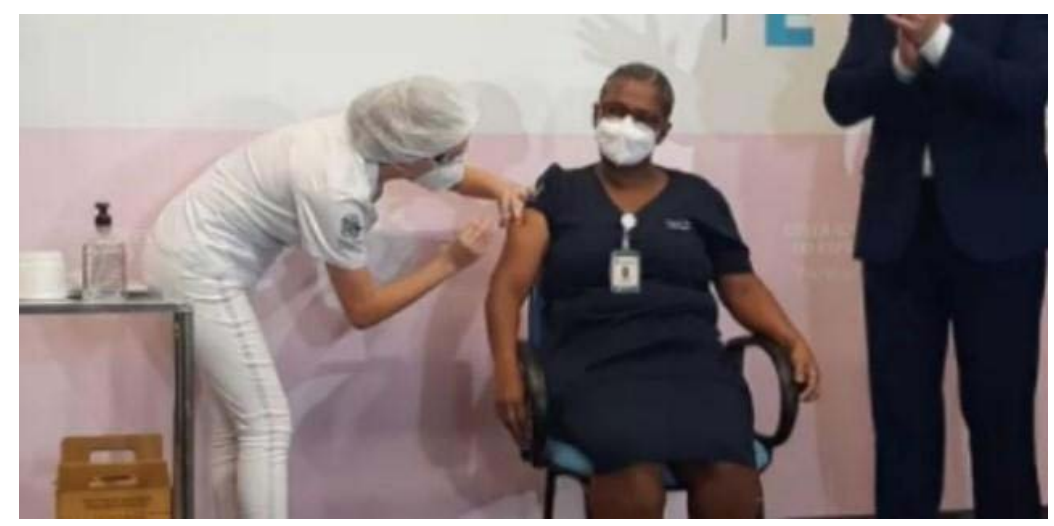

Figura 9 - Técnica de enfermagem vacinada no Espírito Santo Fonte: Cometti e Arpini, 2021.

Nas próximas imagens (10 e 11) vemos duas indígenas vacinadas, a primeira em Mato Grosso do Sul e a segunda, no Amazonas. A primeira é idosa e a segunda, mais jovem. De pronto é possível dizer que independentemente da idade, ambas representam um grupo amplamente discriminado: mulheres, pretas e indígenas somando muitas 'fragilidades'. Na Figura 10, a idosa está no lado inferior esquerdo recebendo a vacina enquanto outros sujeitos, que são mostrados apenas da cabeça para baixo, observam o ato. A mulher aparenta um certo cansaço no olhar, e a cromática prevalecente é o branco vs preto, corroborando com a análise relativas às minorias.

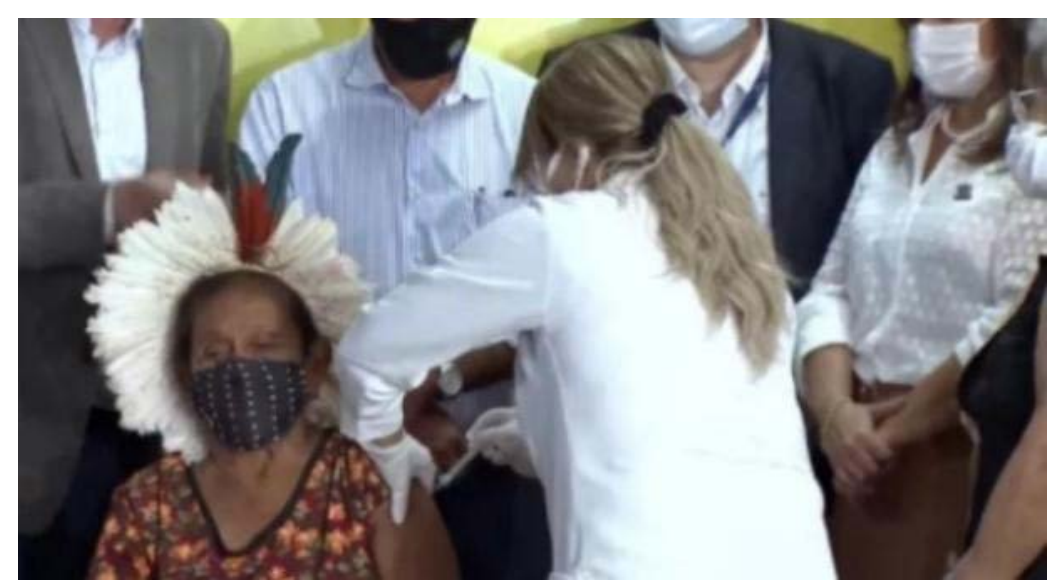

Figura 10 - Indígena vacinada no Mato Grosso do Sul Fonte: Godoy, 2021.

Na imagem seguinte (Figura 11), a técnica de enfermagem indígena de Manaus recebe a vacina e levanta um tipo de chocalho - instrumento usado pelos índios como uma espécie de 'bandeira', que pode significar um reforço de sua cultura. Figurativamente, o feito também se apresenta como um sinal de alívio e de vitória pela chegada deste momento tão aguardado. Na capital do Amazonas, onde fica o 'pulmão do mundo', como as mídias têm dito, as pessoas têm morrido sem ar, devido às complicações da covid-19, muito resultante do colapso no sistema de saúde do estado (REDAÇÃO, 2021). Nesses casos, usaram mulheres que reforçam a ideia e o estereótipo de um Brasil 'mestiço', 'multicultural', da 'miscigenação' e do preconceito contra a mulher que, sendo 'fraca', precisa ser primeiramente vacinada e protegida pelo homem-Estado, reforçando sua imagem de 'homem de ação'. 


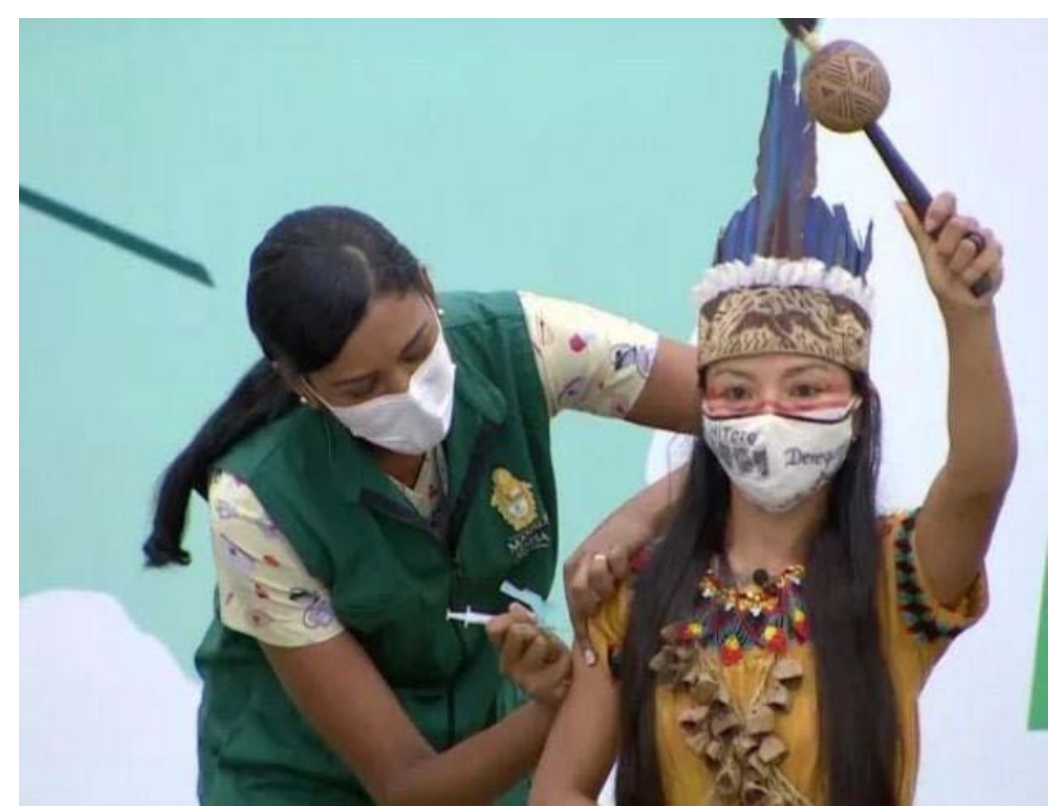

Figura 11 - Técnica de enfermagem indígena é imunizada em Manaus Fonte: Marques e Cruz, 2021.

A questão é sensível e traz na esteira outros temas pertinentes a serem discutidos como os relacionados ao meio ambiente e religião. A próxima foto traz um forte componente simbólico. Na Figura 12, aparecem 'aos pés' do Cristo Redentor as duas primeiras mulheres sendo vacinadas, uma delas idosa de uma instituição da cidade; e a outra uma técnica de enfermagem. A imagem expõe aspectos de crença religiosa e da ciência, temáticas polemizadas política e socialmente no decorrer de toda a pandemia. Simbolicamente, o Cristo abençoa este momento em que o tratamento contra o coronavírus iniciou, atendendo expectativas e anseios da maior parcela da população brasileira, que tem como base a fé cristã.

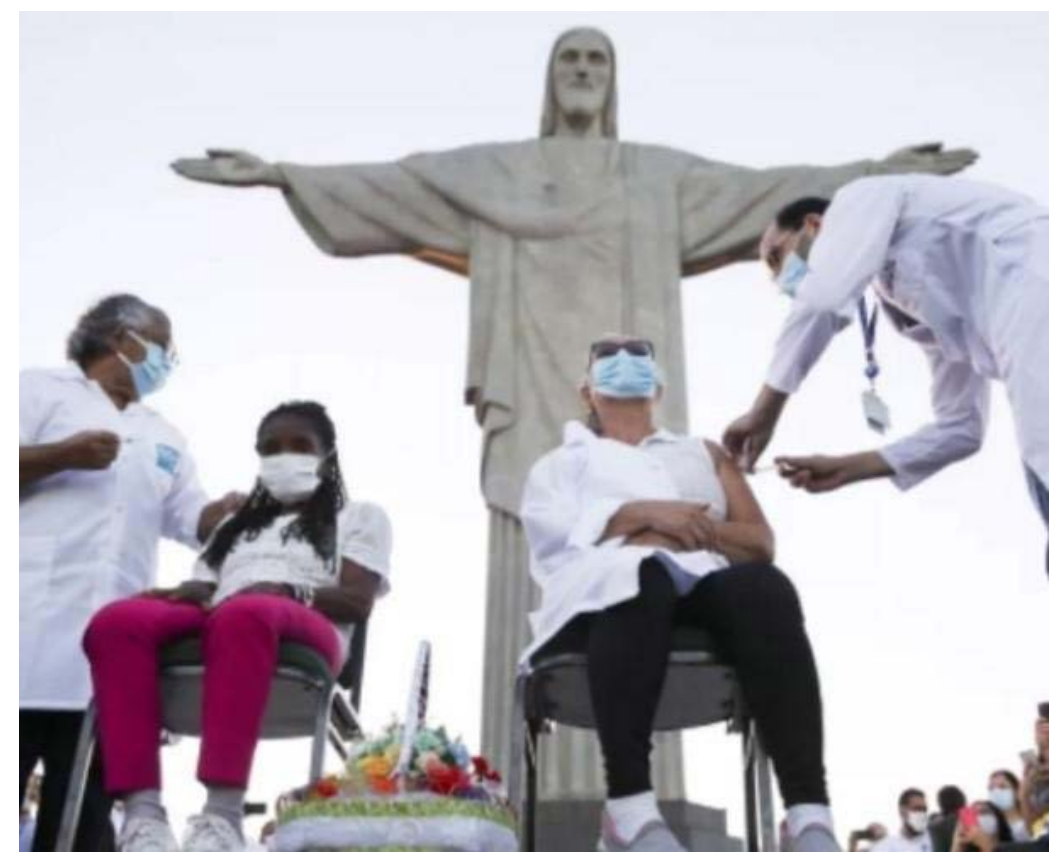

Figura 12 - Idosa e técnica de enfermagem são as primeiras vacinas no Rio de Janeiro Fonte: Satriano, 2021. 
Em Santa Catarina, outra mulher técnica de enfermagem e preta foi a primeira a receber a vacina, conforme a Figura 13. Nesta imagem, vemos o branco que engloba o espaço (cenário) da sala e a cor do uniforme do profissional que aplicou a vacina (homem).

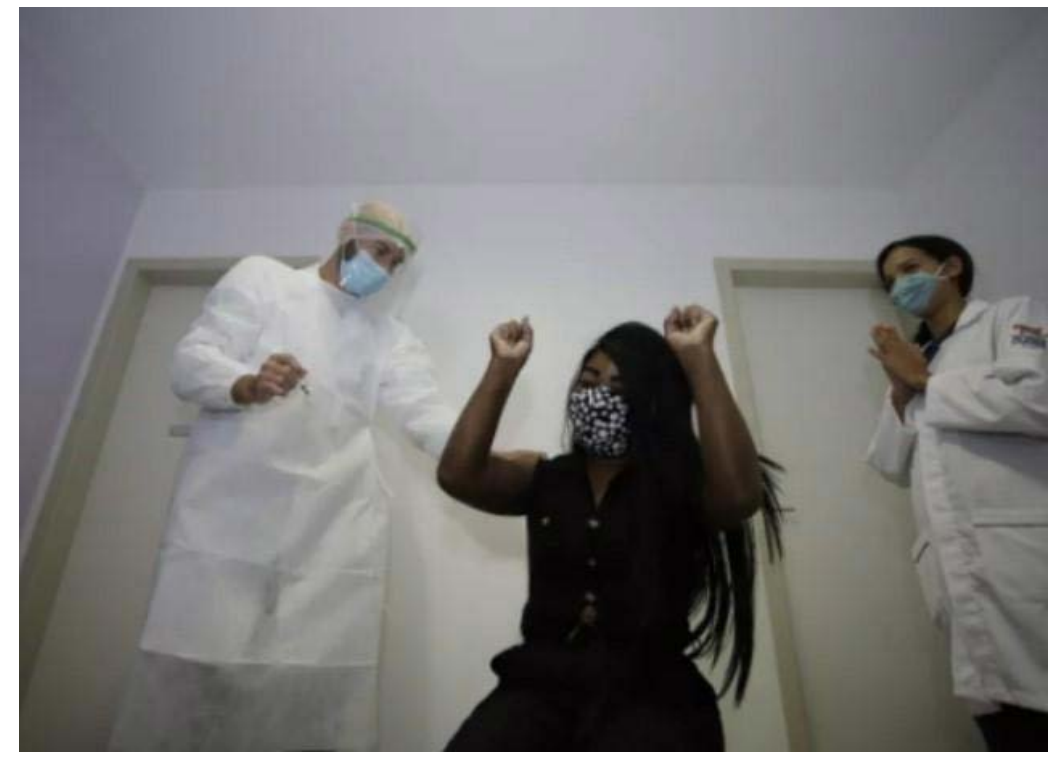

Figura 13 - Técnica de enfermagem vacinada em Florianópolis Fonte: Fernandes, 2021.

O ângulo em que a foto foi feita reforça a mesma topologia constatada anteriormente (alto vs. baixo, superior vs. inferior) como contraste em relação à raça da candidata a receber a imunização, que sentada e vestida com roupas pretas, comemora erguendo as mãos.

Dos elementos semióticos apresentados neste tópico emergem alguns tipos de preconceitos manifestados em diversas ocasiões, de maneira velada: étnico, racial e o de gênero, os mesmos destacados anteriormente por Biroli e Miguel (2015, p. 37) como parte de uma sociedade escravocrata, principalmente nesse caso, à mulher e negra. Mulheres negras se encontram numa posição maior de "subalternidade" que as demais, como apontam Biroli e Miguel (2015, p. 37).

Estes acontecimentos expressam formas de opressões que permanecem imbricadas a uma servidão latente. Ora, se ela pode servir dentro de uma agenda política que engrandece os homens, por sinal todos brancos, que dirá não podem representar a classe das mulheres que mais trabalham? Aqui destacamos semântica e figurativamente o termo escravidão, no qual as pessoas não eram remuneradas nem próximo à altura de tudo que realizavam. Essa fragilidade encontra-se presente em exemplos como os levantados neste estudo.

Biroli e Miguel (2015, p. 38) mostram que mesmo as bandeiras do feminismo e da luta pela igualdade de gênero sejam levantadas de maneira generalizada em relação às mulheres, elas não contemplam diretamente as causas raciais, que necessitam sempre de uma discussão mais ampla. Na maior parte das imagens, é possível perceber a mulher preta em desvantagem e sendo usada como trampolim para alcançar interesses políticos.

Se as mulheres são como um todo tornadas inferiores nos discursos da política e mídia, aquelas que sofrem preconceito racial são ainda mais atingidas. Nas imagens, esses fatos se confirmam na posição das mulheres, ou as mulheres brancas estão aplicando a vacina em outras, que são pretas, ou elas acompanham homens brancos, enquanto a negra é vacinada. Em toda essa escala hierárquica, a mulher preta figura a maior (des)vantagem, tal como descrevem Biroli e Miguel (2015, p. 39). Em suma, como deliberam os autores, "mulheres negras não existem". No discurso da vacina, encenam o papel de protagonista, mas no 
sentido disfórico, suas fragilidades são expostas. Nesse cenário da vacina contracenam com os efeitos do racismo, da "dominação pelo olhar do dominador" (BIROLI; MIGUEL, 2015, p. 39-40). Assim, não está excluso o fato de que a mulher, no geral, sofre preconceito de toda ordem, mas a mulher preta é ainda mais afetada por carregar um fardo que se arrasta histórica e socialmente, simbolicamente prescrito nos elementos disponíveis na análise das linguagens verbal e imagética.

Em conjunto, os autores mencionados no tópico inicial de ‘Gênero, desigualdades e seus efeitos' discutem a libertação desses padrões por quem está cansada de ser submissa e sofrer limitações de toda ordem ou condição. Tais amarras são repetidas vezes nas práticas cotidianas, sejam explícitas ou implícitas, como as que apontamos aqui, e devem sempre ser confrontadas.

Tem que ser forte para aguentar essa carga, carregada por gerações, no entanto, quando se trata de interesses de grupos dominantes, essa característica sofre uma inversão, e o sujeito é tratado como "fraco", aquele que precisa ser primeiramente imunizado. Não fosse assim, quem sabe a mulher preta não teria sido a "personagem principal" escolhida na maior parte das capitais, como mostraram as notícias do G1, a tomar a vacina. O não aceitar essa realidade pode, segundo Biroli e Miguel (2015, p. 49), representar uma forma de dominação ou negação do problema existente, o que não coopera para uma possível solução.

\section{CONSIDERAÇÕES FINAIS}

Este trabalho vai ao encontro de estudos que revelam que, mesmo a mulher tendo uma perspectiva histórica de conquistas pequenas no sentido de respeito e igualdade, no imaginário coletivo ela ainda figura como um sujeito vulnerável. Isso é privilegiado em campanhas de vacinação, que ao mesmo tempo dão certa visibilidade, colocando-as no "centro" dos discursos políticos e midiáticos e demonstram quão 'frágil' se considera esse perfil na sociedade e como elas são usadas para reforçar a imagem do 'homem forte', a visão paternalística do 'pai-provedor'.

Pelas análises do corpus em questão, com base nos conceitos da semiótica discursiva, plástica e figurativa (GREIMAS, 1984), identificamos por meio da linguagem verbal e visual elementos disfóricos que trazem à luz essas fragilidades, oriundas nos efeitos de um sistema desigual. Se estão presentes no dia a dia desta categoria como um todo, que dirá não interferem, como defende Biroli e Miguel (2015), nos aspectos raciais e na vida de mulheres negras? Prova disso é o recorte dessa pesquisa, apontando que de 27 capitais em que a vacina foi aplicada, as primeiras a receber as doses em 21 destas cidades, em meio a um cenário de manipulação e encenações políticas, foram auxiliares de enfermagem pretas, quando não idosas ou indígenas. Este público é visto, de acordo com Saffioti (2011, p. 31), como "inferiores na ordem patriarcal de gênero" e, dessa forma, continua sofrendo sérias opressões.

Sob outra perspectiva, a falta de valorização da mulher no mercado de trabalho a inscreve, em determinadas situações, numa condição de vulnerabilidade econômica e social. Prova disso é que mesmo integrando 70\% das profissionais da saúde, segundo aponta estatística da ONU-Mulher (2020), elas não fazem parte do grupo de tomada de decisões, ficando relegadas a um segundo plano. Dessa forma, será aquela que vai apenas 'executar as ordens', ficando sobrecarregadas, conforme destacou o relatório da ONU.

Os procedimentos relativos às necessidades dos pacientes, que estão na esfera do mais básico ao mais complexo, ficam sob a responsabilidade delas e vão desde a entrada dos doentes no hospital até a montagem de leitos, aplicação de terapias e exames. Como mostrou a PNAD Contínuo (2018), as mulheres atuam em postos de trabalho desempenhando, de acordo com a cultura patriarcal, papéis ou funções destinadas à elas.

Tal informação converge com o que diz Saffioti (2011) na obra Violência, gênero e patriarcado sobre o sexismo, que "reflete não somente uma ideologia, mas, também, uma estrutura de poder, cuja distribuição é muito desigual em detrimento das mulheres" (p. 35). 
Os exemplos dados neste estudo comprovam tais debilidades. Landowski, na obra Presenças do outro (2012), confirma que as desvantagens experimentadas cotidianamente pelo público feminino estão fundadas na ideia do "segundo sexo" (p. 125) e embora não justifiquem, auxiliam na compreensão de que estes desafios não tiveram origem na pandemia e, infelizmente, não vão embora com ela.

Outro ponto importante que levantamos aqui é que elas são sempre as que têm menor remuneração, confirmando o que mostrou o relatório divulgado em 2019, sob o título "Fórum Econômico Mundial vê 2 séculos para fim de desigualdades de gênero no mercado de trabalho" (FRANCE PRESSE, 2019). Além disso, informações obtidas por meio da Pesquisa Nacional de Amostra por Domicílios (SARAIVA; BELLO; RENAUX, 2018) apontam que independentemente de ter ou não curso superior, os salários recebidos e as posições ocupadas pelas mulheres estão aquém do merecido e são sempre inferiores ao que está estabelecido para o sexo oposto - sendo essa mais uma das consequências da infindável condição desigual entre homens e mulheres.

\section{REFERÊNCIAS}

ADOMO, Luís. Enfermeira de SP, negra e moradora de Itaquera é $1^{a}$ vacinada no Brasil. UOL, São Paulo, 17 jan. 2021. Coronavírus. Disponível em: https://noticias.uol.com.br/saude/ultimas-noticias/ redacao/2021/01/17/enfermeira-de-sp-negra-moradora-de-itaquera-e-1-vacinada-no-brasil.htm. Acesso em: 10 fev. 2021.

AFP. Cerca de cinquenta países já começaram a vacinar contra a covid-19. Istoé Dinheiro, [s. I.], 31 dez. 2020. Giro. Disponível em: https://www.istoedinheiro.com.br/cerca-de-cinquenta-paises-ja-comecaram-avacinar-contra-a-covid-19/. Acesso em: 10 fev. 2021.

ALVES, Pedro. 'É um momento histórico para mim e para todos', diz técnica de enfermagem que recebeu $1^{\text {a }}$ dose da vacina em Pernambuco. G1 Pernambuco, Recife, 18 jan. 2021. Disponível em: https://g1.globo. com/pe/pernambuco/noticia/2021/01/18/e-um-momento-historico-para-mim-e-para-todos-diz-tecnica-deenfermagem-que-recebeu-a-primeira-dose-da-vacina-em-pernambuco.ghtml. Acesso em: 20 jan. 2021.

ARAÚJO, Jair Bueno de. Gênero, sexualidade e identidades sexuais - um diálogo entre Joan Scott e Judith Butler. In: II SIMPÓSIO INTERNACIONAL DE EDUCAÇÃO SEXUAL - SIES. Gênero, direitos e diversidade sexual: trajetórias escolares, 2., 2011, Maringá. Anais [...] Maringá: Universidade Estadual de Maringá, 2011. Disponível em: http://www.sies.uem.br/trabalhos/2011/121.pdf. Acesso em: 02 out. 2021.

ARAÚJO, Jair Bueno de; MONASTÉRIOS, Sylvia. Educação, feminismo e contracultura: o pensamento de Betty Friedan. Revista Saber Acadêmico, Presidente Prudente, n. 12, p. 49-53, 2011. Disponível em: http:// uniesp.edu.br/sites/ biblioteca/revistas/20180403120236.pdf. Acesso em: 20 fev. 2021.

BIROLI, Flávia; MIGUEL, Luis Felipe. Gênero, raça, classe: opressões cruzadas e convergências na reprodução das desigualdades. Mediações - Revista de Ciências Sociais, Londrina, v. 20, n. 2, p. 27-55, 2015. DOI: http://dx.doi.org/10.5433/2176-6665.2015v20n2p27. Disponível em: https://www.uel.br/revistas/ uel/index.php/mediacoes/article/view/24124. Acesso em: 1 out. 2021.

BORGES, Flávia. Chegou ao fim toda essa tristeza', diz primeira profissional da saúde vacinada em MT. G1 Mato Grosso, Cuiabá, 18 jan. 2021. Disponível em: https://g1.globo.com/mt/mato-grosso/ noticia/2021/01/18/chegou-ao-fim-toda-essa-tristeza-diz-primeira-profissional-da-saude-vacinada-em-mt. ghtml. Acesso em: 20 jan. 2021.

BOTTALLO, Ana. Veja quais países já iniciaram a vacinação contra a covid-19. Folha de S.Paulo, São Paulo, 28 dez. 2020. Saúde. Disponível em: https://www1.folha.uol.com.br/equilibrioesaude/2020/12/veja-quaispaises-ja-comecaram-a-vacinacao-contra-a-covid-19.shtml. Acesso em: 10 fev. 2021.

BOURDIEU, Pierre. Choses dites. Paris: Minuit, 1987.

BOURDIEU, Pierre. O campo político. Revista Brasileira de Ciência Política, Brasília, DF, n. 5, p. 193-216, 2011. DOI: https://doi.org/10.1590/S0103-33522011000100008. Disponível em: https://www.scielo.br/j/ rbcpol/a/3JY6Zsr9yVZGz8BYr5TfCRG/?lang=pt. Acesso em: 1 out. 2021.

BOURDIEU, Pierre. O poder simbólico. Lisboa: Deifel, 1989. 
CARDOSO, Rafael. Vacinação contra a covid-19 começa no Maranhão com cinco imunizados. G1 Maranhão, São Luís, 18 jan. 2021. Disponível em: https://g1.globo.com/ma/maranhao/noticia/2021/01/18/vacinacaocontra-a-covid-19-comeca-no-maranhao-com-cinco-imunizados-video.ghtml. Acesso em: 20 jan. 2021.

CNN. Veja quais países iniciaram a vacinação contra a covid-19; Brasil está fora. CNN Brasil, São Paulo, 24 dez. 2020. Saúde. Disponível em: https://www.cnnbrasil.com.br/saude/2020/12/24/quais-os-paises-que-jacomecaram-a-vacinacao-contra-a-covid-19. Acesso em: 10 fev. 2021.

COLLINS, Patricia Hill. Black feminist thought: knowledge, consciousness and the politics of empowerment. Nova York: Routledge, 2000.

COMETTI, Any; ARPINI, Naiara. Técnica de enfermagem é a primeira pessoa a receber vacina contra a covid-19 no Espírito Santo. G1 Espírito Santo, Vitória, Disponível em: https://g1.globo.com/es/espiritosanto/noticia/2021/01/18/tecnica-de-enfermagem-e-a-primeira-pessoa-a-receber-vacina-contra-a-covid19-no-espirito-santo.ghtml. Acesso em: 20 jan. 2021.

CRENSHAW, Kimberle. Documento para o encontro de especialistas em aspectos da discriminação racial relativos ao gênero. Revista Estudos Feministas, Florianópolis, v. 10, n. 1, p. 171-188, 2002. DOI: https://doi.org/10.1590/S0104-026X2002000100011. Disponível em: https://www.scielo.br/j/ref/a/ mbTpP4SFXPnJZ397j8fSBQQ/abstract/?lang=pt. Acesso em: 1 out. 2021.

DEMURU, Paolo; GARCIA, Janete Monteiro. De "dama de ferro" a "bruxa desequilibrada": uma análise semiótico-discursiva da figura de Dilma Rousseff na mídia impressa brasileira (2005-2016). Revista Interamericana de Comunicação Midiática Animus, Santa Maria, v. 19, n. 39, 2020. DOI: https://doi. org/10.5902/2175497738941. Disponível em: https://periodicos.ufsm.br/animus/article/view/38941/pdf. Acesso em: 20 ago. 2021

DEMURU, Paolo. Imagens autênticas: corpo, contágio e fotografia política nos tempos do Instagram. Discursos fotográficos, Londrina, v.16, n. 28, p. 203-237, jan.-jun. 2020. Disponível em: https://www.uel.br/ revistas/uel/index.php/discursosfotograficos/article/view/38462/pdf. Acesso em: 20 ago. 2021.

FERNANDES, Carolina. Técnica de enfermagem que atua em UTI de Florianópolis é a primeira vacinada contra Covid-19 entre as capitais do Sul. G1 Santa Catarina, Florianópolis, 19 jan. 2021. Disponível em: https://g1.globo.com/sc/santa-catarina/noticia/2021/01/19/tecnica-de-enfermagem-e-a-primeira-vacinadaem-florianopolis.ghtml. Acesso em: 20 jan. 2021.

FRANÇA, Andréa. Enfermeiras do Hospital de Campanha recebem as primeiras doses da vacina contra covid-19 em Belém. G1 Pará, Belém, Disponível em: https://g1.globo.com/pa/para/noticia/2021/01/19/ enfermeiras-que-atuam-na-linha-de-frente-recebem-as-primeiras-doses-da-vacina-contra-covid-19-embelem.ghtml. Acesso em: 20 jan. 2021.

FRANCE PRESSE. Desigualdade de gênero no trabalho só acabará daqui a 257 anos, aponta Fórum Econômico Mundial. G1, [s. I.], 17 dez. 2019. Economia. Disponível em https://g1.globo.com/economial noticia/2019/12/17/desigualdade-de-genero-no-trabalho-so-acabara-daqui-a-257-anos-aponta-forumeconomico-mundial.ghtml. Acesso em: 1 out. 2021.

FRIEDAN, Betty. Mística feminina. Petrópolis: Vozes, 1971.

G1. IDOSA de 90 anos é a primeira a ser vacinada contra covid-19 no Reino Unido. G1, [s. I.], 8 dez. 2020. Bem Estar. Disponível em: https://g1.globo.com/bemestar/vacina/noticia/2020/12/08/idosa-de-90-anos-e-aprimeira-a-ser-vacinada-contra-covid-no-reino-unido.ghtml. Acesso em: 10 fev. 2021.

G1 BA. Enfermeira é a primeira pessoa a receber a vacina contra a covid-19 na Bahia: 'Me sinto honrada'. G1 Bahia, Salvador, 19 jan. 2021. Disponível: https://g1.globo.com/ba/bahia/noticia/2021/01/19/enfermeira-ea-primeira-pessoa-a-receber-a-vacina-contra-a-covid-19-na-bahia.ghtml. Acesso em: 20 jan. 2021.

GODOY, João Pedro. Indígena de 91 anos é a primeira a receber vacina contra covid-19 em MS. G1 Mato Grosso do Sul, Campo Grande, 18 jan. 2021. Disponível em: https://g1.globo.com/ms/mato-grosso-do-sul/ noticia/2021/01/18/indigena-de-91-anos-e-a-primeira-a-receber-vacina-contra-covid-19-em-ms.ghtml. Acesso em: 20 jan. 2021.

GONZALEZ, Lélia. A mulher negra na sociedade brasileira. In: LUZ, Mater T. (Org.). O lugar da mulher: estudos sobre a condição feminina na sociedade atual. Rio de Janeiro: Edições Graal, 1981. p. 89-106. 
GONZALEZ, Lélia. Racismo e sexismo na cultura brasileira. Revista Ciências Sociais Hoje, São Paulo, p. 223-244, 1984.

GREIMAS, Algirdas Julien. Semiótica figurativa e plástica. Significação: Revista Brasileira de Semiótica, São Paulo, n. 4, 1984. DOI: https://doi.org/10.11606/issn.2316-7114.sig.1984.90477. Disponível em: https:// www.revistas.usp.br/significacao/article/view/90477. Acesso em: 1 out. 2021.

GREIMAS, Algirdas Julien; COURTÉS, Joseph. Dicionário de semiótica. São Paulo: Contexto, 2008.

HOOKS, Bell. Mulheres negras: moldando a teoria feminina. Revista Brasileira de Ciência Política, Brasília, n. 16, p. 193-210, jan.- abr., 2015.

IANNI, Octavio. Raças e classes sociais no Brasil. Rio de Janeiro: Civilização Brasileira, 1972.

INSTITUTO BRASILEIRO DE GEOGRAFIA E ESTATÍSTICA (IBGE). Conheça o Brasil - População: Quantidade de homens e mulheres. IBGEeduca, Rio de Janeiro, [2019]. Disponível em: https://educa.ibge. gov.br/jovens/conheca-o-brasil/populacao/18320-quantidade-de-homens-e-mulheres.html. Acesso em: 17 maio 2021.

KOSSOY, Boris. Realidades e ficções na trama fotográfica. São Paulo: Atelier Editorial, 1999.

LANDOWSKI, Eric. Presenças do outro: ensaios de sociossemiótica. São Paulo: Perspectiva, 2012.

LIMA, Márcia. "Raça" e pobreza em contextos metropolitanos. Tempo social, São Paulo, n. 24, p. 233-254, 2012.

LUHMANN, Niklas. La realidad de los medios de masas. Barcelona: Anthropos Editorial; México: Universidad Iberoamericana, 2005.

MARQUES, Patrick; CRUZ, Victor. Enfermeira indígena Vanda Ortega é a primeira vacinada contra Covid no Amazonas. G1 Amazonas, Manaus, 18 jan. 2021. Disponível em: https://g1.globo.com/am/amazonas/ noticia/2021/01/18/enfermeira-indigena-vanda-ortega-e-a-primeira-vacinada-contra-covid-no-amazonas. ghtml. Acesso em: 20 jan. 2021.

MINORIA. In: DICIONÁRIO ON LINE DE PORTUGUÊS (DICIO). [S. I.]: 7Graus, c2009. Disponível em: https:// www.dicio.com.br/minorial. Acesso em: 17 maio 2021.

ORGANIZAÇÃO DAS NAÇÕES UNIDAS (ONU). ONU Mulheres Brasil. Vozes das mulheres nas linhas de frente da covid-19. Brasília, DF: A Organização, 2020. Disponível em: http://www.onumulheres.org.br/ noticias/vozes-das-mulheres-na-linhas-de-frente-da-covid-19/. Acesso em: 20 jan. 2021.

PINTO-COELHO, Zara; MOTA-RIBEIRO, Silvana. Imagens publicitárias, sintaxe visual e representações da heterossexualidade. Comunicación e Cidadanía, Santiago de Compostela, n. 1, p. 79-94, 2007.

PORDEUS, Marcel Pereira; VIANA, Rosemary de Abreu. Feminismo, desigualdade de gênero e LGBTfobia: a interseccionalidade das minorias no Brasil. Conhecer: Debate Entre O Público E O Privado, Fortaleza, v. 11, n. 26, p. 113-131. DOI: https://doi.org/10.32335/2238-0426.2021.11.26.4651. Disponível em: https://revistas. uece.br/index.php/revistaconhecer/article/view/4651. Acesso em: 1 out. 2021.

REDAÇÃO. Estoque de oxigênio acaba em hospitais de Manaus e região. Estadão, São Paulo, 14 jan. 2021. Saúde. Disponível em: https://saude.estadao.com.br/noticias/geral,estoque-de-oxigenio-acaba-em-hospitaisde-manaus-e-pacientes-morrem-asfixiados,70003581285. Acesso em: 20 mar. 2021.

RODRIGUES, Rodrigo. 'Não tenham medo', diz Mônica Calazans, $1^{\text {a }}$ pessoa a ser vacinada no Brasil. G1 São Paulo, São Paulo, 17 jan. 2021. Disponível em: https://g1.globo.com/sp/sao-paulo/noticia/2021/01/17/naotenham-medo-diz-monica-calazans-1a-pessoa-a-ser-vacinada-no-brasil.ghtml. Acesso em: 20 jan. 2021.

SAFFIOTI, Heleieth I. B. Gênero, patriarcado e violência. São Paulo: Fundação Perseu Abramo, 2011.

SANTANA, Vitor. Moradora de abrigo de idosos é a $1^{\text {a }}$ vacinada contra covid-19 em Goiás: 'Esperei muito tempo por essa vacina'. G1 Goiás, Goiânia, 18 jan. 2021. Disponível em: https://g1.globo.com/go/goias/ noticia/2021/01/18/moradora-de-abrigo-de-idosos-e-a-primeira-goiana-a-receber-a-vacina-contra-acovid-19.ghtml. Acesso em: 20 jan. 2021. 
SANTOS, Mateus da Cunha; FOSSÁ, Maria Ivete Trevisan. A disputa pelo poder político em meio à pandemia de covid-19: análise do confronto entre João Doria e Jair Bolsonaro. Panorama, Goiânia, v. 10, n. 1, p. 8-13, 2020. DOI: http://dx.doi.org/10.18224/pan.v10i1.8297. Disponível em: http://seer.pucgoias.edu.br/index. php/panorama/article/view/8297. Acesso em: 1 out. 2021.

SARAIVA, Adriana; BELLO, Luiz; RENAUX, Pedro. No dia da mulher, estatísticas sobre trabalho mostram desigualdades. Agência IBGE, Rio de Janeiro, 8 mar. 2018. Estatísticas Sociais. Disponível em: https:// agenciadenoticias.ibge.gov.br/agencia-noticias/2012-agencia-de-noticias/noticias/20287-no-dia-damulher-estatisticas-sobre-trabalho-mostram-desigualdade. Acesso em: 20 jan. 2021.

SATRIANO, Nicolás. Duas primeiras moradoras do RJ são vacinadas no Cristo Redentor. G1 Rio de Janeiro, Rio de Janeiro, 18 jan. 2021. Disponível em: https://g1.globo.com/rj/rio-de-janeiro/noticia/2021/01/18/saibaquem-e-serao-as-primeiras-vacinadas-contra-a-covid-19-no-rio.ghtml. Acesso em: 20 jan. 2021.

SINGER, André. Politização da vacina contra covid-19 é estratégia para eleições presidenciais. Jornal da USP, São Paulo, 10 dez. 2020. Rádio USP. Disponível em: https://jornal.usp.br/radio-usp/politizacao-davacina-contra-covid-19-e-estrategia-para-eleicoes-presidenciais/. Acesso em: 5 mar 2021.

SOUZA, Jessé de. A elite do atraso: da escravidão à Lava-Jato. Rio de Janeiro: Leya, 2017. 